\title{
Changes in immune parameters of natural mussel Mytilus edulis populations following a major oil spill ('Sea Empress', Wales, UK)
}

\author{
Elisabeth A. Dyrynda ${ }^{1, *}$, Robin J. Law ${ }^{2}$, Peter E. J. Dyrynda ${ }^{1}$, Carole A. Kelly ${ }^{2}$, \\ Richard K. Pipe ${ }^{3}$, Norman A. Ratcliffe ${ }^{1}$ \\ ${ }^{1}$ School of Biological Sciences, University of Wales Swansea, Singleton Park, Swansea SA2 8PP, United Kingdom \\ ${ }^{2}$ Centre for Environment Fisheries and Aquaculture Science, Burnham Laboratory, Remembrance Avenue, \\ Burnham-on-Crouch, Essex CM0 8HA, United Kingdom \\ ${ }^{3}$ Natural Environment Research Council, Plymouth Marine Laboratory, Citadel Hill, Plymouth, \\ Devon PL1 2PB, United Kingdom
}

\begin{abstract}
In February 1996, the oil tanker 'Sea Empress' spilt over 70000 t of crude oil which contaminated ca $200 \mathrm{~km}$ of coastline (Milford Haven, Wales, UK). The effects of the oil on immunity in mussels Mytilus edulis were investigated in parallel with the measurement of hydrocarbon contamination in the tissues. Initially, severe immunosuppression occurred in oiled mussels, corresponding with very high polycyclic aromatic hydrocarbon (PAH) levels. The haemocytes of mussels from oiled sites showed significantly reduced superoxide generation and phagocytic activity, effects likely to have deleterious consequences for successful disease resistance. As contaminant levels decreased, the immunosuppression became less extreme and recovery was evident by May 1996. Between October 1996 and March 1997, immune activity in the haemocytes of the previously oiled mussels was again significantly reduced, coinciding with increased PAH levels. During this latter period, certain high molecular mass PAHs (characteristically derived from combustion processes) were primarily responsible for the increase, occurring at similar concentrations in the mussel tissues to those observed just after the spill. A subsequent reduction of hydrocarbons in June 1997 was followed by another, but less marked, increase in PAHs between October 1997 and March 1998, coupled with only minimal changes in immunity. The results show that immunosuppression following the oil spill was severe, but that recovery followed a few months later and the initial effects were not therefore permanent. The results also suggest that seasonal peaks in combustion-derived PAHs may occur in the region and that these would have been greatly exacerbated early in 1996 by oil released from the 'Sea Empress'.
\end{abstract}

KEY WORDS: Mytilus $\cdot$ Immune defence $\cdot$ Haemocyte $\cdot$ Oil spill $\cdot$ Hydrocarbon contamination

\section{INTRODUCTION}

Contaminant inputs from various sources continually afflict marine ecosystems and impacts range from mass mortalities to subtle, but adverse, physiological effects. Commercial shipping accidents have caused many oil spill incidents in the marine environment, examples

*E-mail: e.a.dyrynda@swansea.ac.uk including the 'Amoco Cadiz' (1978, France), the 'Exxon Valdez' (1989, USA), the 'Aegean Sea' (1992, Spain), and the Rhode Island spill (1996, USA). The 3 largest spills in UK waters have involved oil tankers, the 'Torrey Canyon' (1967; 119000 t of oil spilt), the 'Braer' (1993; 85000 t) and the 'Sea Empress' (1996; 72000 t) (ITOPF 1999). Research following such incidents has not only described extensive mortalities, but also identified a wide range of sub-lethal impacts on wildlife. 
These include the induction of biomarker enzymes in fish and molluscs (Sole et al. 1996, Woodin et al. 1997, Stagg et al. 1998, Kirby et al. 1999), abnormalities in fish embryos/larvae (Hose et al. 1996, Bue et al. 1998) and haematological changes in vertebrates (Duffy et al. 1994, Walton et al. 1997).

Despite the considerable effects that crude oil contaminants can exert on the physiology of marine animals, information concerning impacts on the physiology of natural invertebrate populations is more limited, particularly with respect to their immune defences. Globally, marine invertebrates constitute an important economic resource, and factors influencing their ability to resist disease and hence maintain healthy populations are of considerable relevance. Invertebrate immune defences comprise cellular and humoral components, which are highly efficient in combating pathogens and parasites and share many facets with vertebrate immune defences (Ratcliffe et al. 1985, Engstrøm et al. 1993). Laboratory exposure to contaminants can significantly alter immunity in invertebrates from diverse phyla, including annelids (Suzuki et al. 1995, Ville et al. 1995), molluscs (Coles et al. 1994, Auffret \& Oubella 1997, Cima et al. 1998), crustaceans (Smith \& Johnston 1992, Smith et al. 1995) and ascidians (Cooper et al. 1995, Cima et al. 1997, Raftos \& Hutchinson 1997). Under laboratory conditions, contaminant-induced immunomodulation can lead to increased susceptibility of molluscs to disease (Winstead \& Couch 1988, Chu \& Hale 1994, Fisher et al. 1999).

Crude oil comprises a mixture of 1000s of components, including polycyclic aromatic hydrocarbons (PAH). Low molecular mass PAHs are among the most acutely toxic components, while some of the high molecular mass PAHs are potent carcinogens. Many PAHs are known immunotoxins, which can affect diverse aspects of immunity in vertebrates and invertebrates (Anderson 1993, Davila et al. 1995, Clemons et al. 1999). Few investigations have been conducted on the effects of PAH contaminants on immune defences in natural invertebrate populations. Sami et al. (1992, 1993) found differences in haemocyte phagocytosis in oysters Crassostrea virginica from PAH-contaminated and PAH-non-contaminated sites, while $C$. virginica transplanted to $\mathrm{PAH}$-contaminated sites showed reductions in macromolecular synthesis by the haemocytes (Faisal \& Demmerle-Sami 1994).

In 1996, the oil tanker 'Sea Empress' ran aground outside Milford Haven (Wales, UK), spilling approximately $72000 \mathrm{t}$ of North Sea Forties blend crude oil and $480 \mathrm{t}$ of fuel oil over the following week. Approximately $200 \mathrm{~km}$ of coastline was contaminated, and the incident ranked as the third largest oil spill in UK waters and among the 20 largest world-wide (SEEEC 1998). Directly after the 'Sea Empress' spill, the current study began to investigate the effects of this largescale pollution incident on immune parameters in natural shellfish populations, using the marine mussel Mytilus edulis as a model. $M$. edulis is a recognised bioaccumulator of contaminants (Widdows \& Donkin 1992) and has been widely used in field monitoring programmes relating to oil contamination (e.g. Widdows et al. 1987, Shigenaka \& Henry 1995). M. edulis is also a common constituent of biological communities, inhabits most types of shore, and is harvested for human consumption. The immune defences of $M$. edulis are largely mediated by the blood cells (haemocytes), which recognise non-self material and subsequently destroy it by ingestion or by the secretion of soluble antimicrobial and cytotoxic molecules (Renwrantz 1990, Hubert et al. 1996).

The current study monitored the effects of the 'Sea Empress' spill in terms of contaminant uptake and retention in tissues, in parallel with evaluations of immune activity in the haemocytes. Initial results covering the first 2 mo after the spill found that immunomodulation in contaminated mussels was severe at first, but appeared to recover as contaminant levels declined (Dyrynda et al. 1997). The work was extended for a total of $2 \mathrm{yr}$ and is the first study to assess the long-term effects of a large-scale oil spill on invertebrate immunity.

\section{MATERIALS AND METHODS}

Oil movement. The 'Sea Empress' was grounded on rocks in the entrance to Milford Haven (Wales, UK) on 15 February 1996 (Fig. 1). The tanker remained stranded, incurring further damage and releasing oil until 21 February 1996, when she was refloated and towed into port, where the remaining cargo was removed. In total, $72000 \mathrm{t}$ of crude oil and $480 \mathrm{t}$ of fuel oil were estimated to have been spilt from the tanker. Much of the spilt oil was dispersed at sea both by natural processes and aerial spraying of oil dispersants, however, it is estimated that ca 15000 t of crude oil/ mousse (water in oil emulsion) reached the shoreline (MPCU 1996, SEEEC 1998). Certain shores near the grounding site suffered heavy, repeated contamination by fresh crude oil and fuel oil during the first few days of the spill. Many shores further afield were subsequently affected by weathered mousse, the largest quantities of which came ashore on the western side of Carmarthen Bay (ca $50 \mathrm{~km}$ east of the grounding area) on 27 February 1996. On rocky shores, it was noted that mussel aggregations, in particular, retained oil residues more readily than most other shore organisms. In subsequent weeks, many shores were re-oiled due to the remobilization of oil slicks, while lower lev- 
Fig. 1. Map of the southwest Wales coastline, showing the extent of the 'Sea Empress' oil spill and the sampling sites

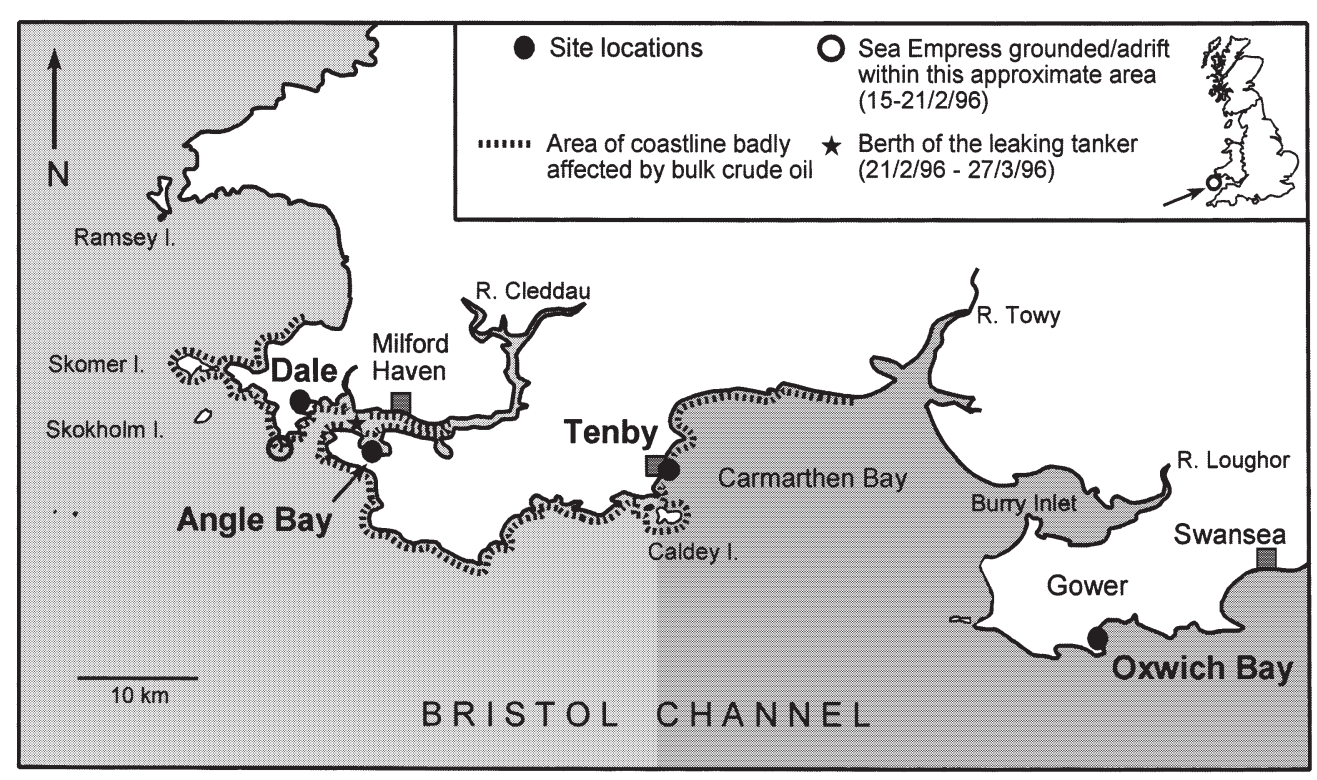

els of re-oiling also occurred periodically in the first 12 mo after the incident, from oil trapped in sandy beaches being released by falling sand levels or storm action. Persistent chronic oiling resulted from the leaching of oil trapped in shingle, a sediment characteristic of many shores in the area. Although some amenity shores were subjected to intensive clean-up procedures during the incident, most rocky shores were left to clear naturally and were affected by persistent oil residues for months after the spill (SEEEC 1998).

Site characteristics. Three oiled sites were monitored, namely Angle Bay, Dale and Tenby (Fig. 1). Angle Bay and Dale are both located inside the mouth of Milford Haven and were among the first shores affected, initially by fresh oil. Tenby (in Carmarthen Bay) became contaminated on 27 February 1996, when large quantities of weathered oil mousse came ashore. Clean-up methods used at Angle Bay and Dale were considered non-damaging to the mussel populations, although more intensive techniques were used at Tenby, including both high-pressure washing and the direct application of dispersants to rocky areas of the shore (MPCU 1996, Moore et al. 1998). The reference site used was Oxwich Bay on the Gower Peninsula, a relatively clean site, which is not subject to any significant anthropogenic stresses. All the sites monitored are moderately sheltered shores, which have a mix of sediment and rock substrata and experience fully saline conditions (>30\%o).

The first samples were collected from Angle and Dale $1 \mathrm{wk}$ after the spill in February 1996. Tenby and Oxwich were not included then as Tenby was still unaffected by the oil and Oxwich was under threat from large offshore oil slicks, which posed a risk to the entire Gower Peninsula. Subsequent samples were collected from all 4 sites in March, April and May 1996, after which they were collected at approximately 3 mo intervals until March 1998. On each occasion, 150 mussels were collected from each site, of which 50 were frozen for hydrocarbon analysis and 100 retained for immune analyses. No commercial exploitation of mussels occurs at these sites.

Hydrocarbon analysis. Full details of the methods used for the analysis of total oil and PAH are given elsewhere (Kelly \& Law 1998, Kelly et al. in press). In brief, whole mussel tissue preparations were produced from 20 individual animals from each sample. The mussels were shucked using stainless steel implements, and the combined whole tissues homogenised using an Ultra-Turrax homogeniser with a stainless steel rotor. Both the whole mussels and tissue homogenates were stored at $-20^{\circ} \mathrm{C}$. The tissue samples were subjected to alkaline saponification under reflux, and the PAH partitioned into $n$-pentane. Analyses for total hydrocarbon concentration (THC) and a suite of individual PAHs (Table 1) were conducted using ultraviolet fluorescence spectrometry and coupled gas chromatography/mass spectrometry respectively. All analyses were conducted under rigorous quality control protocols to safeguard data quality (Kelly \& Law 1998).

Immune analyses. The mussels were allowed to acclimate for $24 \mathrm{~h}$ in an aquarium before analysis. Ten animals were used per assay, and from each mussel $0.5 \mathrm{ml}$ haemolymph was withdrawn via a 23G hypodermic needle into $0.5 \mathrm{ml}$ of either Baker's formol-calcium fixative or Tris-buffered saline (TBS; Dyrynda et 
Table 1. Individual polycyclic aromatic hydrocarbon (PAH) compounds: number of fused rings and molecular masses

\begin{tabular}{|lcc|}
\hline PAH compounds & No. fused rings & $\begin{array}{c}\text { Molecular mass } \\
\text { (Daltons) }\end{array}$ \\
\hline Oil-derived PAHs & & \\
Naphthalene & 2 & 128 \\
C $_{1}$-naphthalenes & 2 & 142 \\
C $_{2}$-naphthalenes & 2 & 156 \\
C $_{3}$-naphthalenes & 2 & 170 \\
Phenanthrene & 3 & 178 \\
C $_{1}$ phenanthrenes and anthracenes & 3 & 192 \\
Combustion-derived PAHs & & \\
Anthracene & 3 & 178 \\
Fluoranthene & 4 & 202 \\
Pyrene & 4 & 202 \\
Benz[a]anthracene & 4 & 228 \\
Chrysene & 4 & 228 \\
2,3-benzanthracene & 4 & 228 \\
Benzo[b] and $[k]$ fluoranthenes & 5 & 252 \\
Benzo[e]pyrene & 5 & 252 \\
Benzo[a]pyrene & 5 & 252 \\
Perylene & 5 & 252 \\
Indeno[1,2,3-cd]pyrene & 6 & 276 \\
Benzo[ghi]perylene & 6 & 276 \\
& & \\
\hline
\end{tabular}

TBS were added per well of a microplate, and $100 \mu \mathrm{l}$ of NBT $\left(4 \mathrm{mg} \mathrm{ml}^{-1}\right.$ in TBS) or NBT plus SOD (300 $\mathrm{U} \mathrm{ml}^{-1}$ ) added immediately to the cells for 30 min at room temperature. The cells were then washed twice by centrifugation $(800 \times g$ for 5 min) with TBS, fixed with methanol for $10 \mathrm{~min}$ and then air-dried after centrifugation as before. The plates were washed 6 times in $50 \%$ methanol and the reaction product of formazan was solubilised by $30 \mathrm{~min}$ incubation with $140 \mu \mathrm{l}$ of $2 \mathrm{M}$ potassium hydroxide and $120 \mu$ of dimethyl sulphoxide per well. Controls included (1) haemocytes plus TBS and (2) NBT/SOD solutions plus TBS alone. The plates were read at $620 \mathrm{~nm}$, and the results calculated per milligram protein.

Phagocytosis: Fifty microlitre aliquots of haemocytes in TBS (4 replicates ind. ${ }^{-1}$ ) were added to microplate wells and left to attach for $20 \mathrm{~min}$ at $20^{\circ} \mathrm{C}$. An equal quantity of neutral-red

al. 1998), as appropriate. Protein quantification of live cells was carried out using the bicinchoninic acid (BCA) assay kit (Pierce \& Warriner, UK).

Total and differential cell counts: Total cell counts (TCC) were made using an improved Neubauer chamber and expressed as the number of haemocytes per millilitre haemolymph. For the differential counts (DCC), haemocyte monolayers were prepared by cytocentrifugation in a Shandon 3 Cytospin, post-fixed with methanol and stained with Wright's stain (BDH) (Dyrynda et al. 1998). Hyaline, basophilic granular and eosinophilic granular haemocytes were counted using a minimum of 200 cells in 4 fields of view.

Extra-cellular release of superoxide anions: This was measured by the reduction of cytochrome $C$, using superoxide dismutase (SOD) to specifically quantify the superoxide anions produced (Pipe et al. 1995a). In brief, $100 \mu \mathrm{l}$ aliquots of haemocytes in TBS ( 3 replicates ind.$^{-1}$ ) were added to microplate wells containing either $100 \mu \mathrm{l}$ of $80 \mu \mathrm{M}$ cytochrome $C$ (in TBS) or cytochrome $C$ plus SOD (300 U ml-1). Controls included (1) haemocytes plus TBS and (2) cytochrome c/SOD solutions plus TBS alone. The plates were read at $550 \mathrm{~nm}$ (narrow band filter) every minute at $20^{\circ} \mathrm{C}$ for a total of $20 \mathrm{~min}$, and the change in optical density calculated per milligram protein.

Intra-cellular generation of superoxide anions: This was measured by the reduction of nitroblue tetrazolium (NBT), also using SOD (Pipe et al. 1995a). Aliquots $\left(100 \mu l, 3\right.$ replicates ind. $\left.{ }^{-1}\right)$ of haemocytes in stained zymosan (Pipe et al. 1995a) $\left(1 \times 10^{8}\right.$ particles $\mathrm{ml}^{-1}$ ) was added to each well for $30 \mathrm{~min}$, after which the cells were fixed with Baker's formol-calcium for $30 \mathrm{~min}$ and then washed 6 times by centrifugation $(150 \times g$ for $5 \mathrm{~min})$. The neutral-red was solubilised with $100 \mu \mathrm{l}$ of acid-alcohol per well (10\% acetic acid and $40 \%$ ethanol in distilled water, incubated for $30 \mathrm{~min}$ ), after which the plate was read at $550 \mathrm{~nm}$. Controls included (1) previously fixed haemocytes plus zymosan and (2) zymosan plus TBS. Phagocytosis was calculated from a standard curve prepared from known amounts of stained zymosan and the results expressed as the amount of zymosan ingested per milligram protein (Pipe et al. 1995a).

Lysosomal enzyme activity: The activity of the lysosomal enzymes $N$-acetyl glucosaminidase (NAG) and chymotrypsin-like enzyme (CTL) were tested as both had previously shown reductions in activity with contaminant exposure (Coles et al. 1994, Dyrynda et al. 1998). The enzymes were measured using a microplate method and tested in lysed haemocytes and cellfree haemolymph. Aliquots $(100 \mu \mathrm{l})$ of haemocytes in TBS (4 replicates ind. ${ }^{-1}$ ) were incubated at $20^{\circ} \mathrm{C}$ for 30 min with either an equal amount of $3 \%$ CHAPS (to lyse the cells and quantify the total activity) or $0.05 \%$ zymosan in TBS (to stimulate the haemocytes). The plates were then centrifuged $(800 \times g$ for $5 \mathrm{~min})$, and $50 \mu \mathrm{l}$ of supernatant per replicate placed into another microplate and incubated for $20 \mathrm{~min}$ at room temperature either with $15 \mathrm{mM} p$-nitrophenyl-glucosaminide 
in $0.2 \mathrm{M}$ citrate buffer (pH 4.5: NAG) or $20 \mathrm{mM} \mathrm{N}$ succinyl-ala-ala-pro-phe-p-nitroanilide in $50 \mathrm{mM}$ TBS (pH 8.0: CTL). Afterwards, a stopping buffer (NAG: $50 \mu \mathrm{l}$ of $0.4 \mathrm{M}$ glycine buffer, $\mathrm{pH} 10.4$; CTL: $50 \mu \mathrm{l}$ of $200 \mu \mathrm{g} \mathrm{ml} \mathrm{m}^{-1}$ soybean-trypsin inhibitor in distilled water) was added to each well and the plates read at $405 \mathrm{~nm}$. Controls comprised (1) haemocytes plus TBS and (2) substrate solution plus TBS. The results were calculated from standard curves of $p$-nitrophenol (NAG) or $p$-nitroaniline (CTL) and expressed per milligram protein.

Lysosomal volume: The uptake of the cationic dye neutral-red, which concentrates in cell lysosomes, was used to assess the volume of the haemocyte lysosomal system (Pipe et al. 1995a). Ten microlitres of $3 \%$ neutralred in TBS were added to $100 \mu$ aliquots (4 replicates ind.$^{-1}$ ) of haemocyte suspension in microplate wells for $30 \mathrm{~min}$ at $20^{\circ} \mathrm{C}$. The cells were then washed twice by centrifugation $(800 \times g$ for $5 \mathrm{~min})$, and the neutral-red solubilised by a 30 min incubation with $10 \%$ acetic acid plus $40 \%$ ethanol in distilled water. Controls included (1) haemocytes plus TBS and (2) neutral-red solution plus TBS alone. The plates were read at $550 \mathrm{~nm}$, and neutral-red uptake calculated per milligram protein.

Statistical analyses. The $\mathrm{PAH}$ concentrations in the tissues were screened by principal component analysis using Systat software (SPSS Inc., Chicago, USA), to look for associations between the individual PAHs (Law et al. 1999). Immune assay data were screened for normality using the Kolmogorov-Smirnov test and subjected to analysis of variance (ANOVA) with a Tukey post hoc test. If appropriate, the data were transformed using arcsine (extracellular superoxide generation) or $\log _{10}$ transformations. Associations between immune parameters and hydrocarbon con- centrations were tested using the Spearman Rank test. For all statistical tests, results were considered significant with a probability $(\mathrm{p})$ value of $<0.05$.

\section{RESULTS}

The large quantities of oil/mousse deposited on the shores were directly responsible for wide-scale, molluscan mortalities, including limpets Patella spp., winkles Littorina spp., razorshells Ensis ensis, cockles Cerastoderma edule and trough shells Mactra corallina (SEEEC 1998). No mortalities arising directly from the oil, however, were obvious in Mytilus edulis populations during the current study. The only dead mussels observed were at Tenby, on rock faces that had been directly subjected to dispersant spraying during April 1996 (Moore et al. 1998).

\section{Hydrocarbon analyses}

Initially, the THC and $\mathrm{PPAH}$ values were extremely high at all 3 oiled sites and declined rapidly between February and October 1996, while still remaining higher than the Oxwich reference site (Figs. 2 \& 3). Between October 1996 and March 1997, THC and $\mathrm{PPAH}$ values rose at Angle, Dale and Tenby, with Oxwich experiencing only a slight increase. Subsequently, the THC and $\mathrm{PAH}$ concentrations declined sharply, before increasing again after October 1997, but to a lesser degree (particularly with respect to the $\Sigma \mathrm{PAH})$ than that observed during the previous year (Figs. 2 \& 3).

The main feature revealed by the principal component analysis was a marked difference with time in the

\section{Total Hydrocarbon Content (THC)}

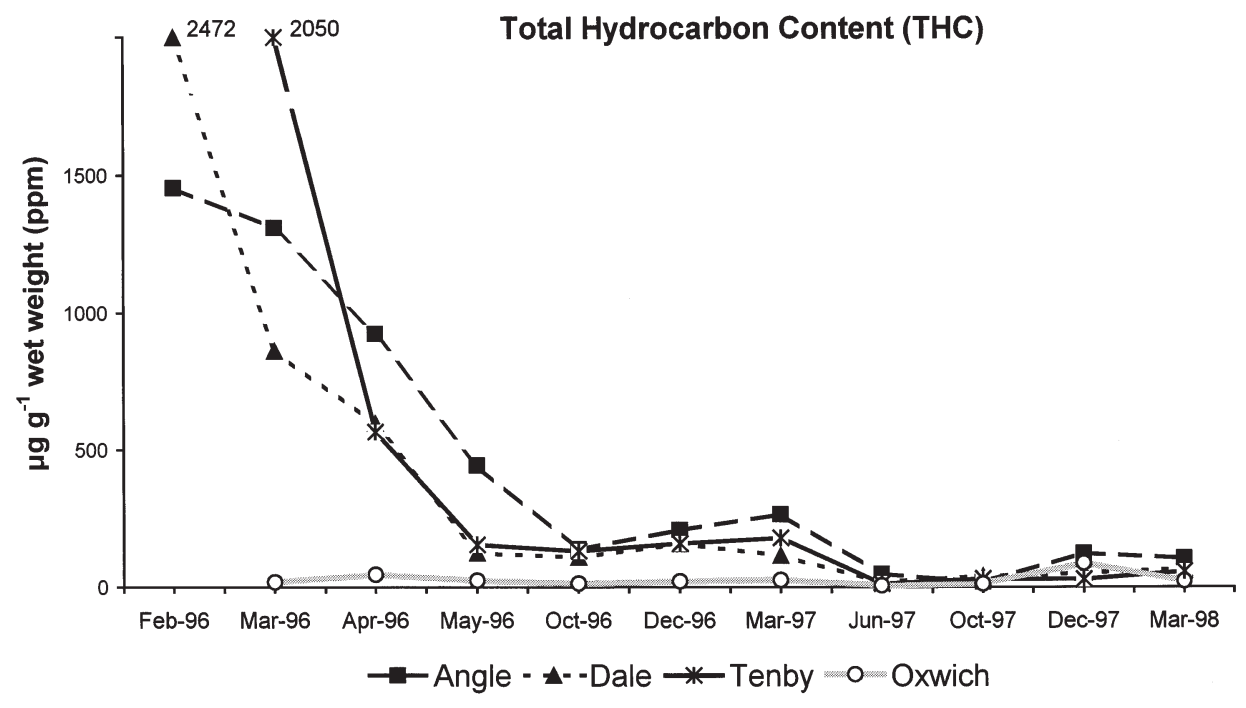

Fig. 2. Total hydrocarbon content (THC) in Mytilus edulis, collected from 4 sites for $2 \mathrm{yr}$ following the 'Sea Empress' oil spill. Numbers on the curves

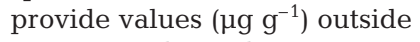
the scale 


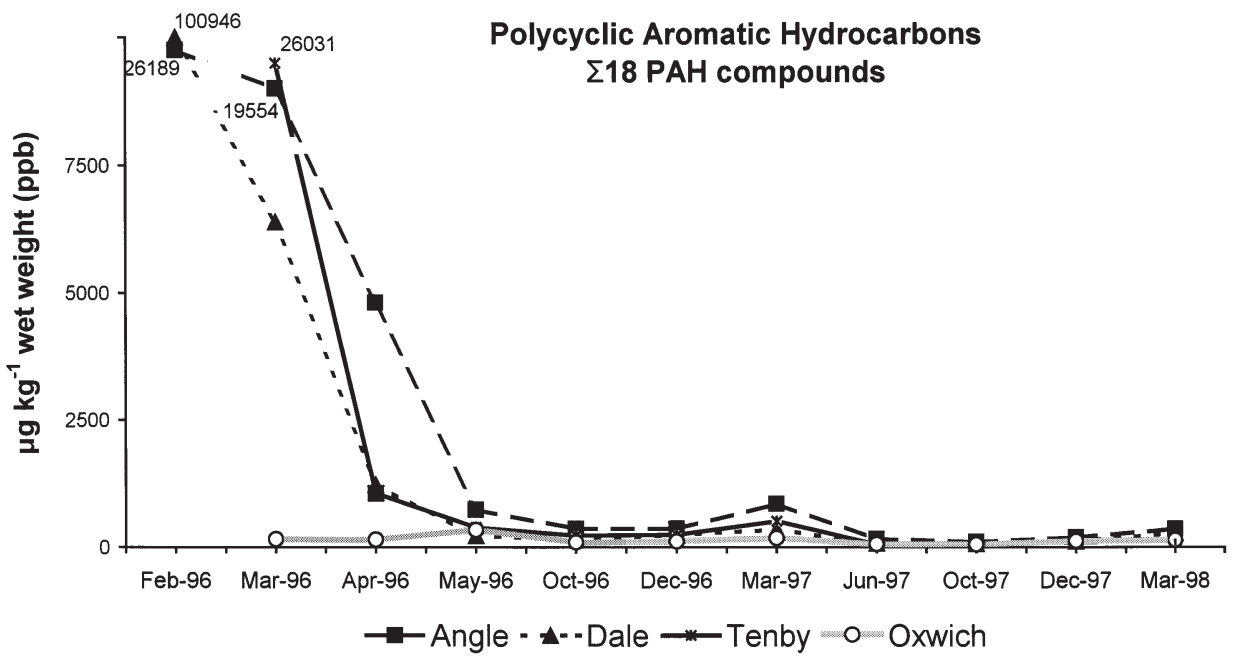

Fig. 3. Polycyclic aromatic hydrocarbon (PAH) content in Mytilus edulis, collected from 4 sites for 2 yr following the 'Sea Empress' oil spill. Data presented as $\sum 18$ individual PAH compounds. Numbers on the curves provide values $(\mu \mathrm{g}$ $\mathrm{kg}^{-1}$ ) outside the scale behaviour of 2 groups of PAHs in the mussel tissues. These comprised 1 group primarily derived from oil and a second primarily derived from combustion processes (Table 1). The concentrations of the oil-derived PAH group in Angle and Dale mussels peaked $8 \mathrm{~d}$ after the grounding in February 1996 (Fig. 4), when oil was no longer being released from the vessel and the bulk oil already lost had moved to the east. At Tenby, the oil-derived PAHs were at their maximum in the March 1996 sample, $10 \mathrm{~d}$ after the arrival of the oil/water mousse in Carmarthen Bay. The concentrations of the combustion PAH group showed their first peaks at An-

\section{Oil-derived PAH}

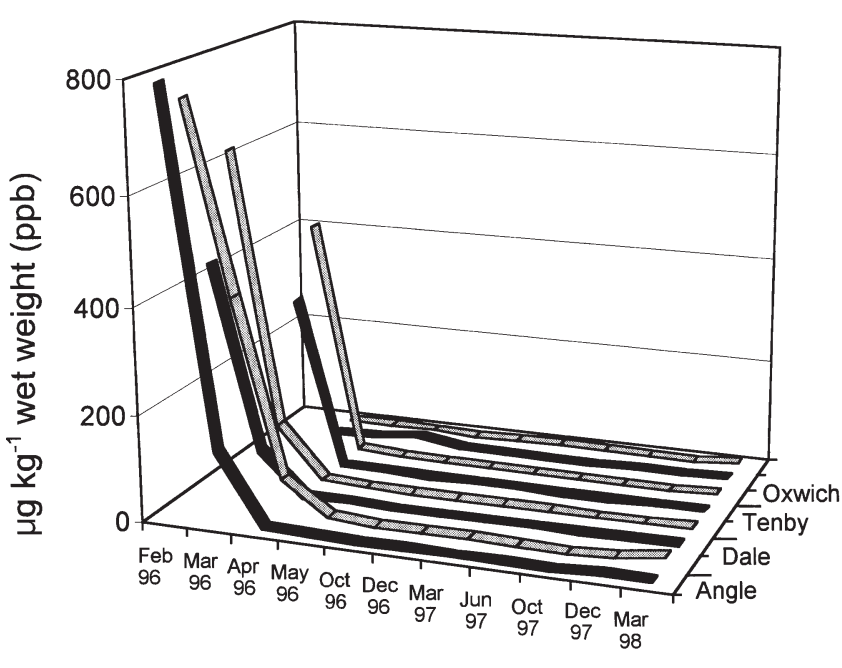

- $\mathrm{C}_{1}$ Naphthalene Phenanthrene

Fig. 4. Individual PAH concentrations in Mytilus edulis, collected from 4 sites for 2 yr following the 'Sea Empress' oil spill. Examples of oil-derived PAH compounds gle, Dale and Tenby in March 1996 (Fig. 5). The concentrations of both groups declined until mid-summer, but the combustion-derived PAH concentrations in Angle, Dale and Tenby mussels increased approximately 1 yr post-grounding in March 1997, reaching similar levels to those observed in March 1996 (Fig. 5). In Oxwich mussels, combustion-derived PAHs also showed an increase, although the values were notably lower than those recorded in Angle, Dale or Tenby mussels (Fig. 5). A similar pattern was observed in the second year of sampling, with low/undetectable levels in June 1997, followed by a small increase at all 4 sites

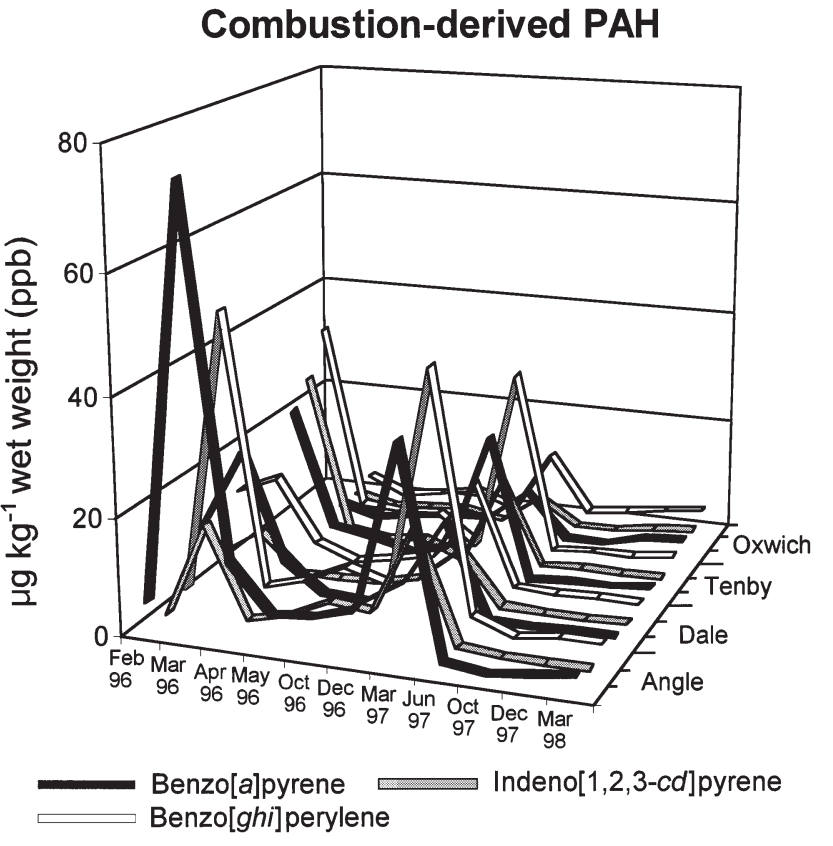

Fig. 5. Individual PAH concentrations in Mytilus edulis, collected from 4 sites for 2 yr following the 'Sea Empress' oil spill. Examples of combustion-derived PAH compounds 
in March 1998. In contrast, the concentrations of the oil PAH group stayed low from May 1996 onwards (Fig. 4) (Law et al. 1999).

\section{Immune parameters}

The analysis of these results for statistical differences was 2 -fold. The primary comparison was between the mean values at each oiled site (Angle, Dale and Tenby) and the mean value of the reference site (Oxwich) at any given sampling date (i.e. between-site differences). Analyses also tested for significant differences between the different sampling dates at each individual site (i.e. time-related differences).

\section{Total and differential cell counts}

Few between-site differences were observed, although in March 1996, TCC values at Angle and Tenby were significantly higher than at Oxwich (Fig. 6). Following the initial sampling, Angle and Dale tended to be lower when compared with Oxwich, although this was only significant in December 1996 (Fig. 6). In general, TCC values at Angle were comparatively low throughout the sampling period, and no significant time-related differences were evident. The TCC values at each of the other sites, however, tended to be significantly lower during earlier stages of the sampling (March/April 1996) than those observed later on (December 1996 to June 1997; Table 2b-d).

The DCC values also showed few significant between-site differences. The percentage of the eosinophilic granular haemocytes at Angle was significantly greater in mussels in May and October 1996 and March 1997, compared with Oxwich (Fig. 7). No statis- tically significant time-related differences in eosinophilic granular cell distributions were found at any of the sites. The percentage of basophilic granular cells showed no significant between-site differences; however, time-related differences at each site were evident (Table 2). At Dale, Tenby and Oxwich this was noticeable between the earlier phases of sampling (March through April 1996) compared with values in October 1996 and the period June to December 1997 (Table $2 b-d)$. The hyaline cells showed only 1 between-site difference at Angle (Fig. 7) and a few time-related (Table 2) differences.

Extra-cellular release of superoxide anions

The levels of extra-cellular superoxide release showed very high peaks at Angle and Dale $1 \mathrm{wk}$ after the spill in February 1996 (Fig. 8), but these decreased very quickly so that no significant between-site differences were observed throughout the overall sampling period (Fig. 8). With respect to time-related differences, the only significant ones occurred at Dale, where superoxide levels in February 1996 were significantly greater than all the other values at that site (Table 2b).

Intra-cellular generation of superoxide anions

The levels of intra-cellular superoxide generation were extremely low at Angle and Dale in February 1996 and were significantly decreased at these 2 sites in March 1996 compared with Oxwich (Fig. 9), while Tenby was significantly lower than Oxwich in both March and April 1996. Intra-cellular superoxide values at all 4 sites were low in October and December 1996,

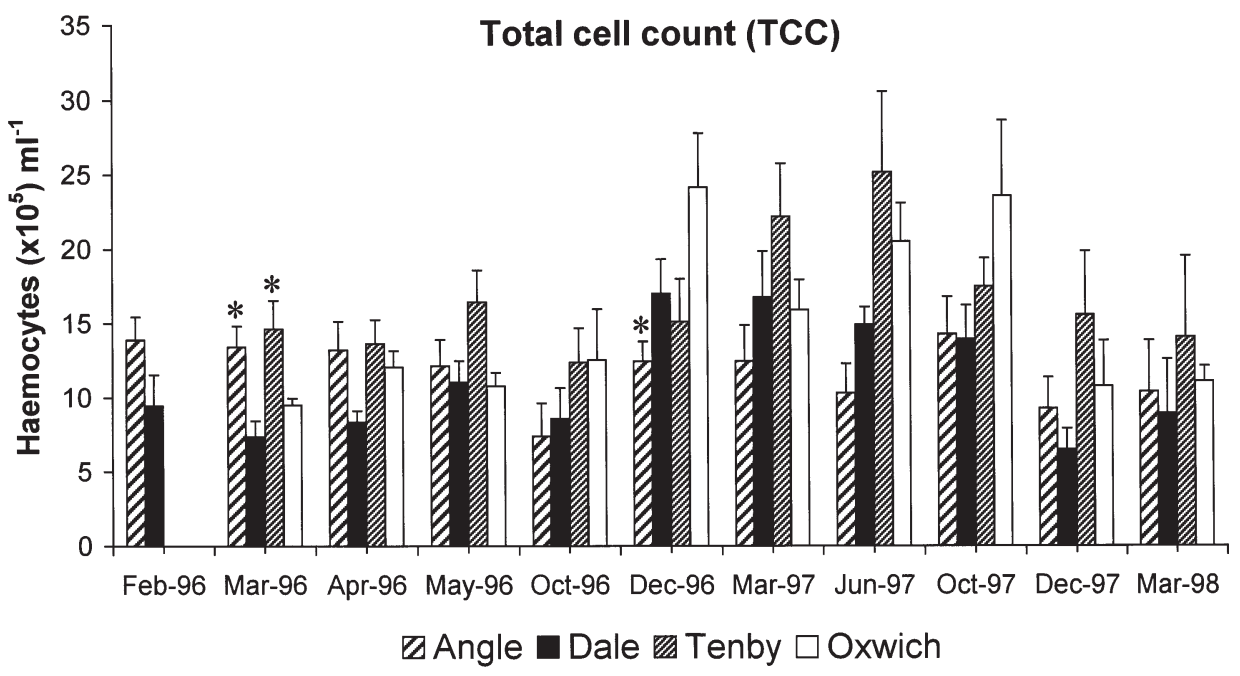

Fig. 6. Total cell count (TCC) of circulating haemocytes from Mytilus edulis collected from 4 sites for $2 \mathrm{yr}$ following the 'Sea Empress' oil spill. Error bars represent $\mathrm{SE}$; *significantly different to the Oxwich value, $\mathrm{p}<0.05$ 
Table 2. Significant differences in immune parameters at each site with time (mo/yr). $\mathrm{T}$, total cell count; $\mathrm{H}$, hyaline cells;

B, basophilic granular cells; , extra-cellular superoxide; $\diamond$, intra-cellular superoxide; $\oplus$, phagocytosis; na, not applicable

\begin{tabular}{|c|c|c|c|c|c|c|c|c|c|c|c|}
\hline & $02 / 96$ & 03/96 & $04 / 96$ & $05 / 96$ & $10 / 96$ & $12 / 96$ & 03/97 & 06/97 & $10 / 97$ & $12 / 97$ & $03 / 98$ \\
\hline \multicolumn{12}{|c|}{ (a) Angle } \\
\hline \multicolumn{12}{|c|}{$02 / 96$} \\
\hline 03/96 & $\diamond$ & & & & & & & & & & \\
\hline $04 / 96$ & $\diamond$ & $\diamond$ & & & & & & & & & \\
\hline $05 / 96$ & $\mathrm{H} \bullet$ & & & & & & & & & & \\
\hline $10 / 96$ & $\bullet$ & & $\diamond$ & & & & & & & & \\
\hline $12 / 96$ & & & $\bullet$ & & & & & & & & \\
\hline 03/97 & $\mathrm{H} \bullet$ & & & & & & & & & & \\
\hline $06 / 97$ & $\mathrm{~B} \bullet \oplus$ & $\oplus$ & & $\oplus$ & & & $\oplus$ & & & & \\
\hline $10 / 97$ & $\diamond$ & & & & & & & $\oplus$ & & & \\
\hline $12 / 97$ & $\bullet$ & & $\diamond$ & & & & & $\oplus$ & & & \\
\hline $03 / 98$ & $\diamond \oplus$ & $\diamond$ & & $\oplus$ & $\bullet$ & $\diamond$ & $\diamond \oplus$ & & $\oplus$ & $\diamond \oplus$ & \\
\hline \multicolumn{12}{|c|}{ (b) Dale } \\
\hline \multicolumn{12}{|c|}{$02 / 96$} \\
\hline 03/96 & 王 & & & & & & & & & & \\
\hline 04/96 & 中 $\diamond$ & & & & & & & & & & \\
\hline $05 / 96$ & 中 & & & & & & & & & & \\
\hline $10 / 96$ & B & B & & & & & & & & & \\
\hline $12 / 96$ & $\mathrm{~T} \oplus \oplus$ & T B & $\mathrm{T}$ & & & & & & & & \\
\hline 03/97 & $\mathrm{T}$ 五 & $\mathrm{T}$ & $\mathrm{T}$ & & & & & & & & \\
\hline $06 / 97$ & $\mathrm{~T} \oplus \bullet \oplus$ & $\mathrm{T} \mathrm{B} \oplus$ & $\mathrm{T}$ & $\oplus$ & $\oplus$ & & $\oplus$ & & & & \\
\hline $10 / 97$ & 中 & B & & & & & & $\oplus$ & & & \\
\hline $12 / 97$ & 里 & $\mathrm{B}$ & & & & & & & & & \\
\hline 03/98 & 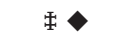 & & & & & $\mathrm{H}$ & & & & & \\
\hline \multicolumn{12}{|c|}{ (c) Tenby } \\
\hline $03 / 96$ & na & & & & & & & & & & \\
\hline 04/96 & na & & & & & & & & & & \\
\hline 05/96 & na & & & & & & & & & & \\
\hline $10 / 96$ & na & B & B & & & & & & & & \\
\hline $12 / 96$ & na & & & & & & & & & & \\
\hline $03 / 97$ & na & & & $\diamond$ & & & & & & & \\
\hline $06 / 97$ & na & T B & $\mathrm{T} B$ & $\mathrm{~T}$ & $\diamond$ & & $\diamond$ & & & & \\
\hline $10 / 97$ & na & $\mathrm{B} \oplus$ & B & $\oplus$ & $\bullet \oplus$ & & $\bullet$ & & & & \\
\hline $12 / 97$ & na & B & $\mathrm{B} \oplus$ & & & $\oplus$ & $\diamond \oplus$ & $\oplus$ & $\oplus$ & & \\
\hline 03/98 & na & $\oplus$ & & $\oplus$ & $\diamond$ & & $\diamond$ & & & $\oplus$ & \\
\hline \multicolumn{12}{|c|}{ (d) Oxwich } \\
\hline $03 / 96$ & na & & & & & & & & & & \\
\hline 04/96 & na & $\mathrm{T}$ & & & & & & & & & \\
\hline 05/96 & na & & & & & & & & & & \\
\hline $10 / 96$ & na & B & $\oplus$ & & & & & & & & \\
\hline $12 / 96$ & na & $\mathrm{T} \mathrm{B} \bullet$ & $\mathrm{T} \diamond$ & $\mathrm{T} \diamond$ & $\oplus$ & & & & & & \\
\hline $03 / 97$ & na & T B & & & & $\diamond$ & & & & & \\
\hline $06 / 97$ & na & $\mathrm{T}$ & & & $\diamond$ & $\bullet$ & & & & & \\
\hline $10 / 97$ & na & $\mathrm{T} B$ & & & $\bullet \oplus$ & $\diamond$ & & & & & \\
\hline $12 / 97$ & na & $\mathrm{B} \oplus$ & $\oplus$ & & & $\diamond \oplus$ & $\oplus$ & $\oplus$ & $\oplus$ & & \\
\hline $03 / 98$ & na & B & & $\mathrm{H}$ & & $\bullet$ & & & & $\oplus$ & \\
\hline
\end{tabular}

and were comparable at the oiled sites with the values observed in March 1996 (Fig. 9). In March 1997, between-site comparisons showed that the levels at Angle, Dale and Tenby were again significantly lower than at Oxwich. In March 1998, superoxide values at Dale, Tenby and Oxwich were all similar; however, those from Angle were significantly higher than Oxwich (Fig. 9), which contrasted starkly with the results of March 1996 and March 1997.
Time-related differences in intra-cellular superoxide levels were evident at all 4 sites. In the haemocytes of the Angle mussels, February 1996 values were significantly lower than all others (bar December 1996), and most values in the series at Angle were significantly lower than the peak at Angle in March 1998 (Table 2a). Similarly, at Dale the February 1996 values were significantly decreased compared with most others in the series (Table 2b). At Tenby, the mean value for March 

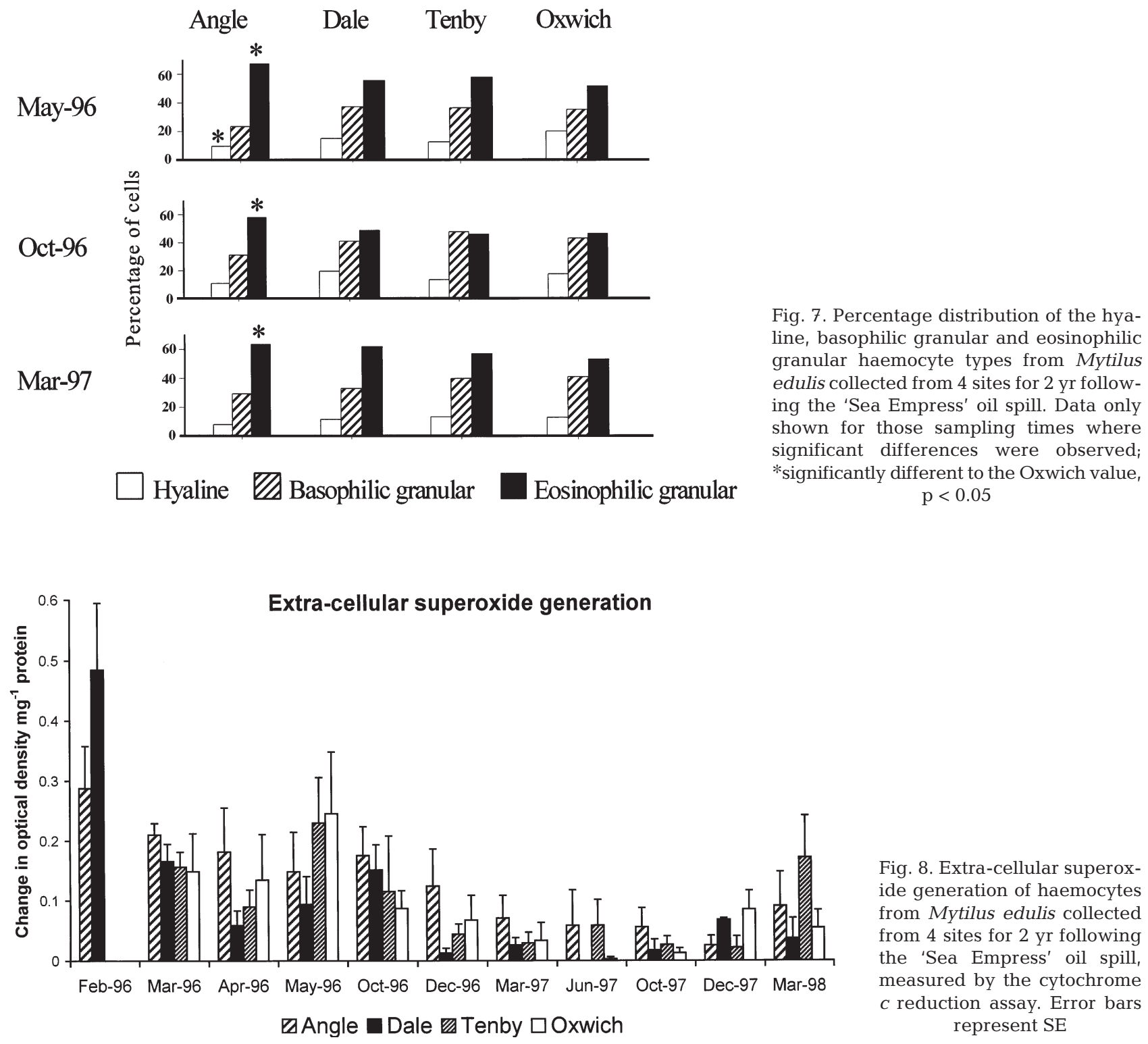

Fig. 8. Extra-cellular superoxide generation of haemocytes from Mytilus edulis collected from 4 sites for $2 \mathrm{yr}$ following the 'Sea Empress' oil spill, measured by the cytochrome $C$ reduction assay. Error bars represent $\mathrm{SE}$

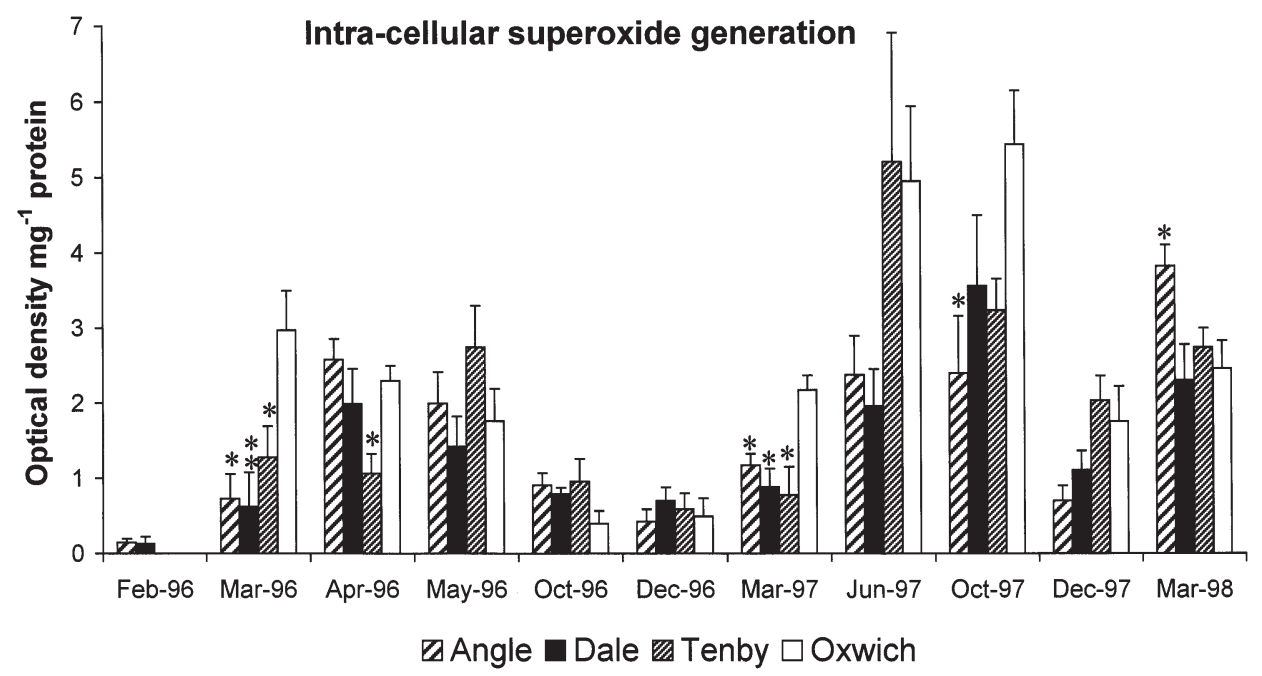

Fig. 9. Intra-cellular superoxide generation in haemocytes from Mytilus edulis collected from 4 sites for $2 \mathrm{yr}$ following the 'Sea Empress' oil spill, measured by the NBT reduction assay. Error bars represent SE. Significant differences to the comparative Oxwich value: $* \mathrm{p}<$ $0.05, *$ * $p<0.01$ 
1997 was significantly lower than those in the period June 1997 to March 1998 (Table 2c). At Oxwich, the values observed in December 1996 were significantly lower than at most other times (Table 2d).

\section{Phagocytosis}

Levels of phagocytosis in Angle and Dale mussels were low in February 1996. Between-site comparisons in March and April 1996 showed that phagocytosis was significantly reduced in mussels from oiled sites compared with ones from Oxwich (Fig. 10). No betweensite differences were found in October 1996, but phagocytosis was again significantly lower at Angle and Tenby in December 1996 and at Angle and Dale in March 1997 when compared with Oxwich. Although increases in phagocytosis at all 4 sites occurred in June and October 1997, values decreased at all the sites in December 1997. While phagocytosis values at the oiled sites tended to be lower than Oxwich in both March 1996 and 1997, the pattern changed in March 1998, when the only between-site difference was the significantly higher value at Dale.

Time-related differences in phagocytosis were numerous at all sites. At Angle and Dale, the higher values observed during June 1997 and March 1998 were significantly greater than at many other sampling times (Table 2a,b). At Tenby, values in the later part of the monitoring programme (October 1997 and March 1998) were significantly different of those during March 1996 to October 1996 (Table 2c). At Oxwich, phagocytosis was variable throughout the sampling period, but the lowest value, observed in December 1997, was significantly different compared with most others in the series (Table $2 \mathrm{~d}$ ).
Lysosomal enzyme activity

Samples from all 4 sites were tested for the activity of NAG and CTL during February to April 1996; however, levels in the haemocytes of mussels from all the sites were barely detectable during this period. No further samples were tested subsequently.

Lysosomal volume

The lysosomal capacity of the haemocytes was tested using the neutral-red uptake assay between February 1996 and May 1996. No between-site differences were evident, and sampling was discontinued after May 1996.

\section{Correlation analyses between hydrocarbons and immune parameters}

The mean values of each immune parameter for each site were tested for correlation with tissue hydrocarbon concentrations. The TCC was associated inversely with only $3 \mathrm{PAH}$, while hyaline cell frequency was associated with $\mathrm{PPAH}, 4$ oil-derived PAHs and 3 combustionderived PAHs (Table 3). In contrast, basophilic and eosinophilic granular cell frequencies showed association with the THC, $\mathrm{PAH}$ and all 18 PAHs measured, the basophilic association being negative and the eosinophilic association positive. Extra-cellular superoxide showed the strongest associations with the oil $\mathrm{PAH}$ group, while intra-cellular superoxide and phagocytosis were associated with both oil- and combustion-derived PAHs, but showed their strongest correlations with the combustion-derived PAHs (Table 3).
Fig. 10. Phagocytic activity of haemocytes from Mytilus edulis collected from 4 sites for $2 \mathrm{yr}$ following the 'Sea Empress' oil spill. Error bars represent SE. Significant differences to the comparative Oxwich value: $* \mathrm{p}<0.05, * \mathrm{w} \mathrm{p}<0.01, * \frac{*}{*} \mathrm{p}<0.001$

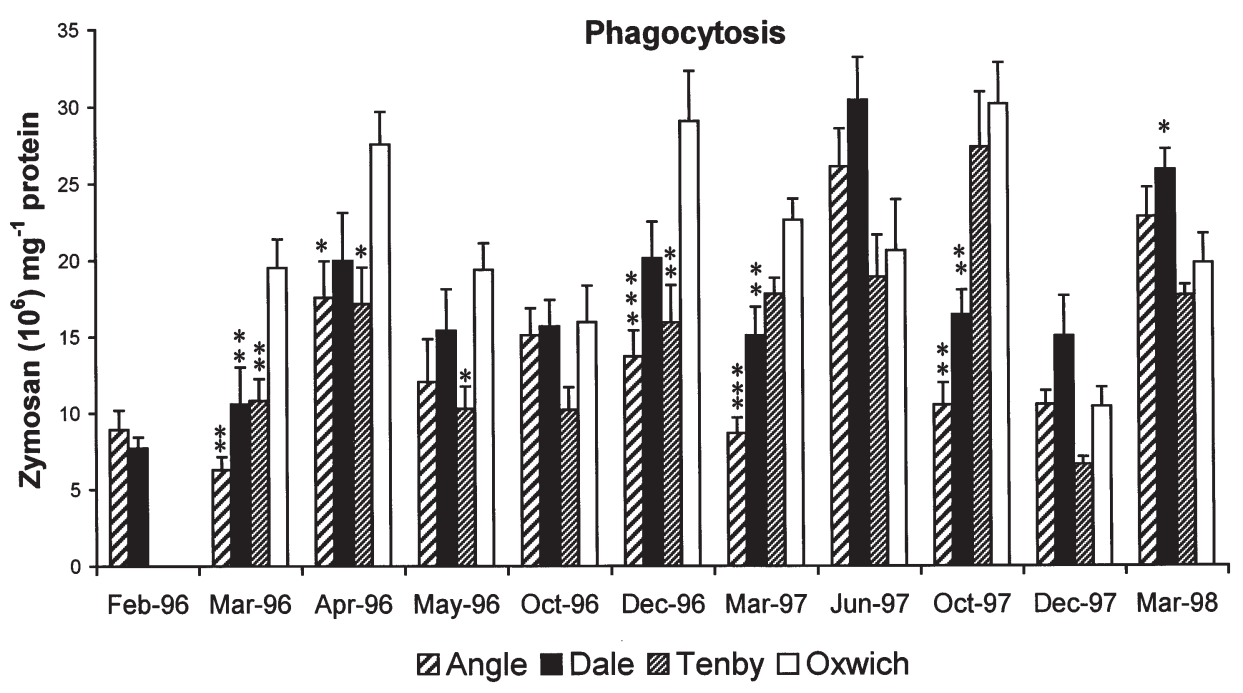




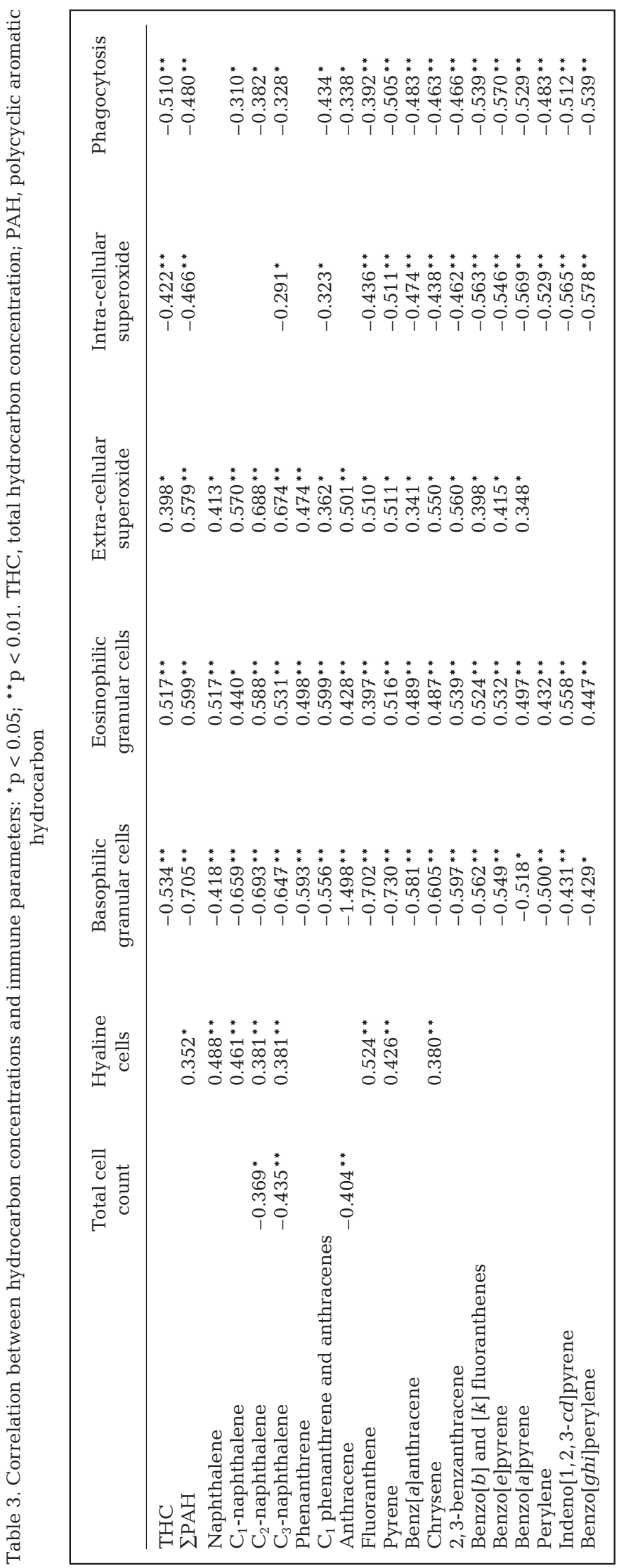

\section{DISCUSSION}

Initial results during the first 2 mo after the oil spill showed impaired immune activity in the mussel haemocytes, which coincided with the extremely high hydrocarbon levels in the tissues. As the hydrocarbon levels declined, immune activity in oiled mussels increased to levels similar to those of mussels from the reference site (Dyrynda et al. 1997). Throughout the 2 yr monitoring period, the greatest overall immunomodulation in comparison with the Oxwich reference site was at Angle and Tenby, sites which featured high levels of hydrocarbons. Immune parameters in Dale mussels, which tended to have lower hydrocarbon concentrations than mussels at Angle or Tenby, showed fewer differences when compared with Oxwich.

Longer-term monitoring has provided evidence of a possible cyclical pattern in hydrocarbon concentrations, which was entirely masked by the oil spill. The increased tissue levels of combustion-derived PAHs during autumn/winter coincide with the period when mussels store lipids in preparation for spawning, and may also reflect higher inputs arising from land run-off during increased rainfall, and the greater need for heating or power generation during the colder months of the year. Similar patterns have also been found in mussels from the North Sea with respect to the combustion-derived PAH benzo[a]pyrene (Jacob et al. 1997) and with respect to $\Sigma \mathrm{PAH}$ in mussels transplanted to sites in the area of the 'Braer' oil spill (Webster et al. 1997). The reductions in hydrocarbons during each spring/summer are probably attributable to rapid depuration during spawning, rather than metabolism of the hydrocarbons, a process believed to be minimal in molluscs. Mix et al. (1982) found that the PAH body burden in Mytilus edulis reduced with spawning, while Ellis et al. (1993) found that the gonads of Crassostrea virginica contained significantly more PAH than somatic tissue.

The most striking results from the immune assays in the present study concerned superoxide generation and phagocytosis, parameters particularly important in cellular immunity. Invertebrate defence relies heavily on the cellular ingestion of non-self material, and the internal production of oxygen metabolites is an important mechanism for killing infectious agents. Intracellular superoxide values in mussels from oiled sites were exceptionally low immediately after the spill and were also significantly reduced in March 1997, coinciding with the later period of increased combustionderived PAH levels. The effects of pollutants on the generation of reactive oxygen species by invertebrate blood cells has frequently been tested using the chemiluminescence assay, which, unlike the SOD-inhibition NBT assay, does not specifically measure superoxide. 
A study using the chemiluminescence assay tested a variety of compounds (including naphthalene) on Crassostrea virginica haemocytes and found generally that high contaminant concentrations depressed the response (Larsson et al. 1989). Pipe et al. (1995b) used the NBT assay on the haemocytes of mussels from the Venice lagoon and found that intra-cellular superoxide appeared greater during periods of lower organic contaminant concentrations (principally PCBs; PAHs were not measured). NBT reduction has also been used to investigate haemocyte superoxide generation in $C$. virginica, and significant effects were found with both date and site differences (Fisher et al. 1996). The 2 sites in that study, however, were within the same, relatively unpolluted bay, and differences were attributed to the interaction of environmental/biological factors creating unique local conditions.

Regarding the extra-cellular release of superoxide anions, these values were extremely high at Angle and Dale immediately after the spill, coinciding with the period in which oil-derived PAHs were at their maximum levels. The extra-cellular superoxide levels declined swiftly and showed little variation thereafter, with no significant between-site differences. Coles et al. (1994) found in a laboratory study that extra-cellular superoxide, measured by cytochrome $c$ reduction, increased with exposure to the PAH fluoranthene. Excessive quantities of superoxide can induce oxidative damage in tissues (Livingstone \& Pipe 1992), and increased levels are therefore potentially harmful. Evidence of oxidative damage has been found in mussels following the 'Aegean Sea' oil spill (Sole et al. 1996).

In the current study, phagocytosis by the haemocytes followed similar patterns to the intra-cellular superoxide values, in that phagocytosis was also exceptionally low in the immediate wake of the spill and showed reductions in the December 1996 to March 1997 period. Phagocytosis in molluscs has generally been found to decrease with increasing exposure to PAH or water/oil mixes. McCormick-Ray (1987) exsposed Mytilus edulis to crude oil emulsion and found that, although the number of granular haemocytes increased, the phagocytic activity was reduced, results similar to those of the current study. The experimental exposure of $M$. edulis to phenathrene, anthracene and fluoranthene also led to decreased phagocytosis in the haemocytes, both with the individual PAHs and in mixtures of the three (Grundy et al. 1996).

The limited number of field surveys on molluscan haemocyte phagocytosis show variable results. In the Venice lagoon, phagocytosis by Mytilus galloprovincialis haemocytes was highly variable, but did show some correlation with contaminant levels (Pipe et al. 1995b). In the Bay of Biscay (Spain), phagocytosis by M. galloprovincialis haemocytes was higher in mussels at a site known to have low levels of PAH contaminants (Cajaraville et al. 1996). In the UK, mussels from contaminated sites showed no significant differences in phagocytosis compared with reference sites (Dyrynda et al. 1998); however, the sites in that study were more likely to be affected by metal contaminants than organic ones. A field survey using the oyster Crassostrea virginica showed that phagocytosis varied more strongly with time, although some variation between the 2 sites tested was evident (Fisher et al. 1996).

It is believed that the effects of PAHs on phagocytosis can arise from the interactions of these lipophilic compounds with cell membranes. The recognition of non-self matter can involve surface binding by lectins to cells (Sharon 1984), followed by membrane invagination to engulf the foreign matter (Beron et al. 1995, Brown 1995); therefore, any disruption of the membrane is likely to severely affect the process. Sami et al. (1992) reported that the haemocytes of oysters from $\mathrm{PAH}$-contaminated sites showed reduced phagocytic activity as well as reduced capacity to bind the lectin Concanavalin A (Con A). Depuration of the oysters from these sites was accompanied by increased Con A binding and enhanced phagocytosis. In the same study, oysters were also exposed to PAH-contaminated sediments, and reduced binding of Con A was again recorded. The work by Sami et al. (1992) supports the hypothesis that changes at the surface of the plasma membrane could affect phagocytosis in invertebrate haemocytes exposed to contaminants. Research on lectin binding and contaminant exposure in invertebrates has, to date, been minimal, but recent work has shown that reduced binding of snowdrop Galanthus nivalis lectin and snail Helix pomatia lectin occurs in mussels exposed experimentally to the inorganic contaminant copper (Pipe et al. 1999).

Not all the immune parameters measured initially after the 'Sea Empress' spill were affected. Although enzyme activity in Mytilus edulis haemocytes had shown changes with fluoranthene exposure (Coles et al. 1994), neither of the enzymes measured in the current study were detectable in early samples, possibly due to seasonal variation which can affect haemocyte enzyme activity (Carballal et al. 1997, Dyrynda et al. 1998). The neutral-red uptake assay was quantifiable, but no between-site differences were evident. This assay has previously shown that the lysosomal system of molluscan cells becomes enlarged with exposure to metals (e.g. Etxeberria et al. 1994, Coles et al. 1995). The results of the present study suggest that such effects might be less likely with PAH contamination, and therefore the assay may be most appropriate in assessing the effects of inorganic contaminants.

The immunosuppression observed in the present study did not arise from lower numbers or proportions 
of haemocytes, which agrees with previous laboratory and field observations of Mytilus edulis (Coles et al. 1994, 1995, Dyrynda et al. 1998). The TCC values in the present study showed no significant reductions in the oiled mussels at times when their immune parameters were significantly impaired. The eosinophilic granular cells in $M$. edulis are the most active in phagocytosis and superoxide production (Pipe et al. 1997), yet the numbers of eosinophils in mussels from oiled sites either showed no significant reductions or were increased compared with the reference site while these immune parameters were reduced.

Correlation analysis was carried out to test for any statistically significant associations between the biological and chemical results. This found that extra-cellular superoxide was most strongly correlated with the low molecular mass, oil-derived PAHs such as naphthalene, while intra-cellular superoxide and phagocytosis showed their strongest associations with the 5and 6-ring, combustion-derived compounds such as benzo[a]pyrene. Extra-cellular superoxide has previously been shown to increase with laboratory exposure to fluoranthene (Coles et al. 1994); however, to date no laboratory work has specifically tested any effects of individual high molecular mass PAHs on superoxide generation or phagocytosis. Anderson et al. (1981) tested the effects of the 6-ring PAH benzo[a]pyrene on bacterial clearance by haemocytes of the clam Mercenaria mercenaria and found that clearance was significantly reduced in the exposed animals, something that could have resulted either from decreased levels of antibacterial molecules, impaired enzymatic/oxygenmediated killing mechanisms or reduced phagocytosis.

The statistical associations observed in the current study between the cells, cellular activity and PAH concentrations do not demonstrate cause and effect. While it is possible that particular immune processes could be affected differently by individual PAHs, it is also possible that the correlations may reflect the role of other factors interacting independently with both cells and hydrocarbons. Whereas extra-cellular superoxide values and the oil-derived PAHs shared only 1 simultaneous peak in the immediate aftermath of the spill, the data for intra-cellular superoxide, phagocytosis and combustion-derived PAHs present a more complex situation. A possible linking factor between these latter elements could be the reproductive cycle, which can affect haemocytes and which is also a means by which molluscs can remove hydrocarbons. A field study in Spain on Mytilus galloprovincialis recorded strong seasonal effects on haemocyte numbers, which were attributed principally to reproductive effects (Santarém et al. 1994). Alternatively, factors such as salinity or temperature can influence bivalve immunity (Fisher \& Newall 1986, Chu \& LaPeyre 1993), although they may have less direct roles than the reproductive cycle in hydrocarbon accumulation/depuration.

An added complication at Tenby was the application of dispersants, which occurred approximately $4 \mathrm{wk}$ after the arrival of the oil at that site. The dispersants were sparingly applied to rock faces contaminated by persistent encrustations of weathered oil mousse, including some rocks supporting mussel assemblages. A proportion of these mussels died a few days later (Moore et al. 1998), and it is unknown whether this mortality arose from direct exposure to dispersant alone or to the oil/dispersant combination. The population of mussels sampled from Tenby in the current study was not directly sprayed with dispersants, and it is likely that oil/dispersant mixtures originating from sprayed rock faces would be quickly diluted by the first high tide after spraying. The level of exposure to dispersants is therefore not considered to be significant compared with the oil exposure, reflected by the high hydrocarbon concentrations in the tissues. In addition, the limited application of biologically tested dispersants in this incident is not comparable with the largescale, indiscriminate use of dispersants during the 'Torrey Canyon' oil spill in 1967, which resulted in deleterious effects on the marine fauna (Smith 1970).

In conclusion, the present study found that Mytilus edulis populations were able to survive extensive heavy oiling, in contrast to other bivalves which suffered mortalities after the 'Sea Empress' oil spill. Despite their survival, significant changes in the immune parameters of heavily oiled $M$. edulis occurred, severely impairing the phagocytic and internal killing mechanisms of haemocytes, which could seriously compromise the resistance of the mussels to bacteria and parasites. The initial severity of immune impairment was not, however, maintained in the oiled mussels, and no significant between-site differences in immunity were observed in samples collected 3 to 6 mo after the spill. Longer-term sampling revealed further increased concentrations of combustion-derived PAHs in mussel tissues 10 to 12 mo after the spill, which were considerably higher in tissues of the previously oiled mussels than in those from the reference site. Parallel measurements of haemocyte immune parameters showed that mussels from the previously oiled sites were undergoing a second bout of reduced immune activity, compared with those unaffected by the original oil spill. Correlation analysis showed statistically significant associations between the immune parameters and the PAHs - with extra-cellular superoxide values associated more strongly with low molecular mass, oil-derived PAHs and intra-cellular superoxide and phagocytosis with the high molecular mass, combustion-derived compounds. Overall, the results of the current study agree with laboratory observations con- 
cerning the effects of oil/PAHs on immunity and confirm that immunosuppression following actual pollution incidents in the field is severe, but not necessarily permanent. The results also illustrate the advantages of longer-term field monitoring, which detected a second bout of contamination/immunosuppression $1 \mathrm{yr}$ after the spill.

Acknowledgements. The authors would like to thank the Natural Environment Research Council (GR3/10815), the Ministry of Agriculture, Fisheries and Food (funding for PAH analyses undertaken by CEFAS), the Royal Society, the Wellcome Trust (Fellowship to E.A.D.: 043537/Z/95/BS/RB) and the University of Wales (Fellowship to E.A.D.) for their support.

\section{LITERATURE CITED}

Anderson RS (1993) Modulation of nonspecific immunity by environmental stressors. In: Couch JA, Fournie JW (eds) Advances in fisheries science: pathobiology of marine \& estuarine organisms. CRC Press, London, p 483-510

Anderson RS, Giam CS, Ray LE, Tripp MR (1981) Effects of environmental pollutants on immunological competency of the clam, Mercenaria mercenaria: impaired bacterial clearance. Aquat Toxicol (Amst) 1:187-195

Auffret M, Oubella R (1997) Haemocyte aggregation in the oyster Crassostrea gigas: in vitro measurement and experimental modulation by xenobiotics. Comp Biochem Physiol 118A:705-712

Beron W, Alvarez-Dominguez C, Mayorga L, Stahl PD (1995) Membrane trafficking along the phagocytic pathway. Trends Cell Biol 5:100-104

Brown EJ (1995) Phagocytosis. Bioessays 17:109-117

Bue BG, Sharr S, Seeb JE (1998) Evidence of damage to pink salmon populations inhabiting Prince William Sound, Alaska, two generations after the Exxon Valdez oil spill. Trans Am Fish Soc 127:35-43

Cajaraville MP, Olabarrieta I, Marigomez I (1996) In vitro activities in mussel haemocytes as biomarkers of environmental quality: a case study in the Abra estuary (Biscay Bay). Ecotoxicol Environ Saf 35:253-260

Carballal MJ, Lopez C, Azevedo C, Villalba A (1997) Enzymes involved in defence functions of haemocytes of mussel Mytilus galloprovincialis. J Invertebr Pathol 70: 96-105

Chu FE, Hale RC (1994) Relationship between pollution and susceptibility to infectious disease in the eastern oyster Crassostrea virginica. Mar Environ Res 38:243-256

Chu FE, LaPeyre JF (1993) Perkinsus marinus susceptibility and defence-related activities in eastern oysters Crassostrea virginica: temperature effects. Dis Aquat Org 16: 223-234

Cima F, Ballarin L, Sabbadin A, Burighlel P (1997) Triphenyltin pesticides in seawater as immunotoxins for tunicates. Mar Chem 58:267-273

Cima F, Marin MG, Matozzo V, Da Ros L, Ballarin L (1998) Immunotoxic effects of organotin compounds in Tapes philippinarum. Chemosphere 37:3035-3045

Clemons E, Arkoosh MR, Casillas E (1999) Enhanced superoxide anion production in activated peritoneal macrophages from English sole (Pleuronectes vetulus) exposed to polycyclic aromatic compounds. Mar Environ Res 47: 71-87
Coles JA, Farley SR, Pipe RK (1994) Effects of fluoranthene on the immunocompetence of the common marine mussel Mytilus edulis. Aquat Toxicol (Amst) 30:367-379

Coles JA, Farley SR, Pipe RK (1995) Alteration of the immune response of the common marine mussel Mytilus edulis resulting from exposure to cadmium. Dis Aquat Org 22: $59-65$

Cooper EL, Arizza V, Cammarata M, Pellerito L, Parrinello N (1995) Tributyltin affects phagocytic activity of Ciona intestinalis haemocytes. Comp Biochem Physiol 112C: 285-289

Davila DR, Davis DP, Campbell K, Cambier JC, Zigmond LA, Burchiel SW (1995) Role of alterations in $\mathrm{Ca}^{2+}$-associated signalling pathways in the immunotoxicity of polycyclic aromatic hydrocarbons. J Toxicol Environ Health 45: $101-126$

Duffy LK, Bowyer RT, Testa JW, Faro JB (1994) Evidence for recovery of body mass and haptoglobulin values of river otters following the Exxon Valdez oil spill. J Wildl Dis 30: 421-425

Dyrynda EA, Law RJ, Dyrynda PEJ, Kelly CA, Pipe RK, Graham KL, Ratcliffe NA (1997) Modulations in cell-mediated immunity of the mussel, Mytilus edulis following the Sea Empress oil spill. J Mar Biol Assoc UK 77:281-284

Dyrynda EA, Burt GR, Pipe RK, Ratcliffe NA (1998) Modulations in immunity of mussels (Mytilus edulis) from contaminated sites in the UK. Aquat Toxicol (Amst) 42:169-185

Ellis MS, Choi KS, Wade TL, Powell EN, Jackson TJ, Lewis DH (1993) Sources of local variation in polynuclear aromatic hydrocarbon and pesticide body burden in oysters (Crassostrea virginica) from Galveston Bay, Texas. Comp Biochem Physiol 106C:689-698

Engstrøm Y, Kadalayil L, Sun SC, Samakovlis C, Hultmark D, Faye I (1993) $\kappa B$-like motifs regulate the induction of immune genes in Drosophila. J Mol Biol 232:327-333

Etxeberria M, Sastre I, Cajaraville MP, Marigomez I (1994) Digestive lysosome enlargement induced by experimental exposure to metals $(\mathrm{Cu}, \mathrm{Cd}$, and $\mathrm{Zn})$ in mussels collected from a zinc-polluted site. Arch Environ Contam Toxicol 24:338-345

Faisal M, Demmerle-Sami S (1994) Polyaromatic hydrocarbons modulate the macromolecular synthesis in haemocytes of the eastern oyster (Crassostrea virginica). In: Stolen JS, Fletcher TC (eds) Modulators of fish immune responses, Vol. 1. SOS Publications, Fair Haven, p 235-246

Fisher WS, Newall RIE (1986) Salinity effects on the activity of granular haemocytes of American oysters, Crassostrea virginica. Biol Bull (Woods Hole) 170:122-134

Fisher WS, Oliver LM, Edwards P (1996) Hematologic and serologic variability of Eastern oysters from Apalachicola Bay, Florida. J Shellfish Res 15:555-564

Fisher WS, Oliver LM, Walker WW, Manning CS, Lytle TF (1999) Decreased resistance of eastern oysters (Crassostrea virginica) to a protozoan pathogen (Perkinsus marinus) after sublethal exposure to tributyltin oxide. Mar Environ Res 47:185-201

Grundy MM, Howell SM, Moore MN, Ratcliffe NA (1996) Phagocytic reduction and effects on lysosomal membranes by polycyclic aromatic hydrocarbons. Aquat Toxicol (Amst) 34:273-290

Hose JE, McGurk D, Marty GD, Hinton DE, Brown ED, Baker TT (1996) Sublethal effects of the Exxon Valdez oil spill on herring embryos and larvae: morphological, cytogenetic and histopathological assessments, 1989-1991. Can J Fish Aquat Sci 53:2355-2365

Hubert F, Noël T, Roch P (1996) A member of the arthropod defensin family from edible Mediterranean mussels 
(Mytilus galloprovincialis ). Eur J Biochem 240:302-306

ITOPF (International Tanker Owners Pollution Federation) (1999) Past spill statistics. ITOPF, London (accessed: 16/03/99); available at http://www.itopf. com/stats.html

Jacob J, Grimmer G, Hildebrandt A (1997) Long-term decline of atmospheric and marine pollution by polycyclic aromatic hydrocarbons (PAHs) in Germany. Chemosphere 34:2099-2108

Kelly CA, Law RJ (1998) Monitoring of PAH in fish and shellfish following the Sea Empress incident. In: Edwards R, Sime H (eds) The Sea Empress oil spill: proceedings of the international conference held in Cardiff, 11-13 February 1998. Chartered Institute of Water and Environmental Management, London, p 467-473

Kelly CA, Law RJ, Emerson HS (in press) Methods of analysis for polycyclic aromatic hydrocarbons (PAH) in marine samples. Science Series Analytical Methods, CEFAS, Lowestoft

Kirby MF, Neall P, Tylor T (1999) EROD activity measured in flatfish from the area of the Sea Empress oil spill. Chemosphere 38:2929-2949

Larsson KG, Roberson BS, Hetrick FM (1989) Effect of environmental pollutants on the chemiluminescence of haemocytes from the American oyster Crassostrea virginica. Dis Aquat Org 6:131-136

Law RJ, Kelly CA, Nicholson MD (1999) Polycyclic aromatic hydrocarbons (PAH) in shellfish affected by the Sea Empress oil spill in Wales in 1996. Polycycl Aromat Comp $17: 229-239$

Livingstone DR, Pipe RK (1992) Mussels and environmental contaminants: molecular and cellular aspects. In: Gosling E (ed) The mussel Mytilus: ecology, physiology, genetics and aquaculture. Elsevier, Amsterdam, p 425-464

McCormick-Ray MG (1987) Haemocytes of Mytilus edulis affected by Prudhoe Bay crude oil emulsion. Mar Environ Res 17:107-122

Mix MC, Hemingway SJ, Schaffer RL (1982) Benzo[a]pyrene concentrations in somatic and gonad tissues of bay mussels Mytilus edulis. Bull Environ Contam Toxicol 28:46-51

Moore JJ, Little AE, Dyrynda PEJ (1998) The ecological effects of shoreline clean-up. In: Edwards R, Sime H (eds) The Sea Empress oil spill: proceedings of the international conference held in Cardiff, 11-13 February 1998. Chartered Institute of Water and Environmental Management, London, p 474-480

MPCU (Marine Pollution Control Unit) (1996) The Sea Empress incident. Final Report. The Coastguard Agency, Department of Transport, Southampton, UK

Pipe RK, Coles JA, Farley SR (1995a) Assays for measuring immune response in the mussel Mytilus edulis. In: Stolen JS, Fletcher TC, Smith SA, Zelikoff JT, Kaattari SL, Anderson RS, Söderhäll K, Weeks-Perkins BA (eds) Techniques in fish immunology. Fish immunology technical communications, Vol 4. Immunological and pathological techniques of aquatic invertebrates. SOS Publications, Fair Haven, p 93-100

Pipe RK, Coles JA, Thomas ME, Fossato VV, Pulsford AL (1995b) Evidence for environmentally derived immunomodulation in mussels from the Venice lagoon. Aquat Toxicol (Amst) 32:59-73

Pipe RK, Farley SR, Coles JA (1997) The separation and characterisation of haemocytes from the mussel, Mytilus edulis. Cell Tissue Res 289:537-545

Pipe RK, Coles JA, Carissan FMM, Ramanathan K (1999) Copper induced immunomodulation in the marine mussel Mytilus edulis. Aquat Toxicol (Amst) 46:43-54

Raftos DA, Hutchinson A (1997) Effects of common estuarine pollutants on the immune reactions of tunicates. Biol Bull (Woods Hole) 192:62-72

Ratcliffe NA, Rowley AF, Fitzgerald SW, Rhodes CP (1985) Invertebrate immunity: basic concepts and recent advances. Int Rev Cytol 97:183-350

Renwrantz L (1990) Internal defence system of Mytilus edulis. In: Stefano GB (ed) Neurobiology of Mytilus edulis. Manchester University Press, Manchester, p 256-275

Sami S, Faisal M, Huggett RJ (1992) Effects of laboratory exposure to sediments contaminated with polycyclic aromatic hydrocarbons on the haemocytes of the American oyster Crassostrea virginica. Mar Environ Res 32:131-135

Sami S, Faisal M, Huggett RJ (1993) Alterations in cytometric characteristics of haemocytes from the American oyster Crassostrea virginica exposed to a polycyclic aromatic hydrocarbon-contaminated environment. Mar Biol 113: $247-252$

Santarém MM, Robledo JAF, Figueras A (1994) Seasonal changes in haemocytes and serum defence factors in the blue mussel Mytilus galloprovincialis. Dis Aquat Org 18: $217-222$

SEEEC (Sea Empress Environmental Evaluation Committee) (1998) The environmental impact of the Sea Empress oil spill. Final Report. The Stationery Office, London

Sharon N (1984) Surface carbohydrates and surface lectins are recognition determinants in phagocytosis. Immunol Today 5:143-147

Shigenaka G, Henry CB Jr (1995) Use of mussels and semipermeable membrane devices to assess bioavailability of residual polynuclear aromatic hydrocarbons three years after the Exxon Valdez oil spill. In: Wells PG, Butler JN, Hughes JS (eds) Exxon Valdez oil spill: fate and effects in Alaskan waters. American Society for Testing and Materials, Philadelphia, p 239-260

Smith JE (ed) (1970) 'Torrey Canyon' pollution and marine life. A report by the Plymouth Laboratory of the Marine Biological Association of the UK. Cambridge University Press, Cambridge

Smith VJ, Johnston PA (1992) Differential haemotoxic effects of polychlorinated biphenyl congeners in the common shrimp Crangon crangon. Comp Biochem Physiol 101C: 641-649

Smith VJ, Swindlehurst RJ, Johnston PA, Vethaak AD (1995) Disturbance of host defence capability in the common shrimp Crangon crangon by exposure to harbour dredge spoils. Aquat Toxicol (Amst) 32:43-58

Sole M, Porte C, Biosca X, Mitchelmore CL, Chipman JK, Livingstone DR, Albaiges J (1996) Effects of the Aegean Sea oil spill on biotransformation enzymes, oxidative stress and DNA adducts in digestive gland of the mussel (Mytilus edulis L.). Comp Biochem Physiol 113C:257-265

Stagg RM, Robinson C, McIntosh AM, Moffat CF, Bruno DW (1998) The effects of the Braer oil spill, Shetland Isles, Scotland, on P4501A in farmed Atlantic salmon (Salmo salar) and the common dab (Limanda limanda). Mar Environ Res 46:301-306

Suzuki MM, Cooper EL, Eyambe GS, Goven AJ, Fitzpatrick LC, Venables BJ (1995) Polychlorinated biphenyls depress allogeneic natural cytotoxicity by earthworm coelomocytes Environ Toxicol Chem 14:1697-1700

Ville P, Roch P, Cooper EL, Masson P, Narbonne JF (1995) PCBs increase molecular-related activities (lysozyme, antibacterial, haemolysis, proteases) but inhibit macrophage-related functions (phagocytosis, wound healing) in earthworms. J Invertebr Pathol 65:217-224

Walton P, Turner CMR, Austin G, Burns MD, Monaghan P (1997) Sublethal effects of an oil pollution incident on 
bredding kittiwakes Rissa tridactyla. Mar Ecol Prog Ser 155:261-268

Webster L, Angus L, Topping G, Dalgarno EJ, Moffat CF (1997) Long-term monitoring of polycyclic aromatic hydrocarbons in mussels (Mytilus edulis) following the Braer oil spill. Analyst (Lond) 122:1491-1495

Widdows J, Donkin P (1992) Mussels and environmental contaminants: bioaccumulation and physiological aspects. In: Gosling E (ed) The mussel Mytilus: ecology, physiology, genetics and aquaculture. Elsevier, Amsterdam, p 383-424

Widdows J, Donkin P, Salkeld PN, Evans SV (1987) Measurement of scope for growth and tissue hydrocarbon concen-

Editorial responsibility: Otto Kinne (Editor),

Oldendorf/Luhe, Germany trations of mussels (Mytilus edulis) at sites in the vicinity of Sullom Voe: a case study. In: Kuipers J, Van den Brink WJ (eds) Fate and effects of oil in marine ecosystems. Nijhoff, Dordrecht, p 269-277

Winstead JT, Couch JA (1988) Enhancement of protozoan Perkinsus marinus infections in American oysters Crassostrea virginica exposed to the chemical carcinogen $n$ nitrosodiethylamine (DENA). Dis Aquat Org 5:205-213

Woodin BR, Smolowitz RM, Stegeman JJ (1997) Induction of cytochrome P4501A in the intertidal fish Anoplarchus purpurescens by Prudhoe Bay crude oil and environmental induction in fish from Prince William Sound. Environ Sci Technol 31:1198-1205

Submitted: September 6, 1999; Accepted: May 16, 2000 Proofs received from author(s): October 9, 2000 